\title{
Dispersal Syndromes Related to Edge Distance in Cerrado Sensu Stricto Fragments of Central-Western Brazil
}

\author{
André Vitor Fleuri Jardim ${ }^{1 *}$ and Marco Antônio Batalha ${ }^{2}$ \\ ${ }^{I}$ Divisão de Acreditação de Organismos de Certificação, Instituto Nacional de Metrologia, Normalização e \\ Qualidade Industrial; Rua Santa Alexandrina, 416; 20261-232, Rio de Janeiro - RJ - Brasil; ${ }^{2}$ Departamento de \\ Botânica; Universidade Federal de São Carlos; C. P.: 676; 13565-905; São Carlos - SP - Brasil
}

\begin{abstract}
The main selective forces affecting the fruiting strategies are related to the environment in which plants occur. As a savanna, microclimatic conditions should not vary in relation to distance from edge in cerrado sensu stricto fragments. Thus, we postulated that the importance of different dispersal syndromes would not vary towards the fragment core. Our aim was to test in four cerrado sensu stricto fragments in central Brazil whether the absolute density of anemo-, auto-, and zoochorous individuals varied in relation to edge distance. According to results, the absolute density of anemo- and autochorous individuals did not vary, whereas those of zoochorous individuals increased with edge distance, pointing out that there were other factors rather than abiotic conditions shifting zoochorous species to the interior of cerrado sensu stricto fragments.
\end{abstract}

Key words: central-western Brazil, cerrado, dispersal, edge effect

\section{INTRODUCTION}

Dispersal is a unidirectional movement of an organism away from its place of birth, which, in higher plants, occurs mostly as seeds (Levin et al., 2003). Seed dispersal is a multi-step process that links successive generations of plants (Fuentes, 2000 ), determining not only the potential area of plant recruitment but also serving as a template for subsequent processes, such as predation, competition, and mating (Nathan and MullerLandau, 2000). It is presumed to have fitness advantages for plants, such as increasing the chances of founding a lineage in a new locality, or reducing density-dependent mortality (Hughes et al., 1994), and is important to community structure and dynamics, specifically to local species composition and its spatial and temporal turnover (Levin et al., 2003).

For the ecological dispersal classes, established on the basis of the dispersing agents, a general set of characteristics called "dispersal syndrome" has been described (van der Pijl, 1972). Plant species may be classified according to their dispersal syndromes into anemochorous, when their diaspores are dispersed by the wind; autochorous, when their diaspores are dispersed by the mechanisms exerted by the plant itself, which may use some outside influence (wind, rain, touching animals, gravity, alternating dry and humid weather conditions) to act; or zoochorous, when their diaspores are dispersed by the animals (van der Pijl, 1972). Even if classifying plant species according to their dispersal syndromes is not a

*Author for correspondence: avjardim@inmetro.gov.br 
substitute for studying dispersal processes, syndromes are useful as general organizing tools (Howe and Smallwood, 1982).

The Cerrado domain is the second largest Brazilian phytogeographical province, originally occupying nearly one-fourth of Brazil's land surface, especially in the Central Plateau (Ratter et al., 1997). The cerrado flora has two components, a woody one and an herbaceous one, which are distinct and antagonistic (Coutinho, 1990; Batalha and Martins, 2007). In the woody component of the cerrado flora, zoochory is the most frequent dispersal syndrome, followed by anemo- and autochory (Gottsberger and SilberbauerGottsberger, 1983; Oliveira, 1998; Batalha and Mantovani, 2000; Batalha and Martins, 2004).

The cerrado vegetation has a high physiognomical variation (Coutinho, 1990): grasslands (campo limpo), shrub savannas (campo sujo), savanna woodlands (campo cerrado), woodlands (cerrado sensu stricto), and tall woodlands (cerradão). The importance of dispersal syndromes changes from open to closed cerrado physiognomies, with a decrease in anemo- and autochory and an increase in zoochory (Gottsberger and SilberbauerGottsberger, 1983; Oliveira and Moreira, 1992).

The main selective forces affecting the fruiting strategies are related to, among other factors, the environment in which plants occur (Opler et al., 1980), as, for example, the edge or interior of vegetation fragments. In human-fragmented forests, the fragments are usually surrounded by a matrix of low biomass and structural complexity (pastures, croplands), so differences in microclimate between the two sides of the edge emerge and create a gradient of temperature and moisture that runs perpendicular to the edge these are the abiotic edge effects (Murcia, 1995; Ramos and Santos, 2006). The different responses among species to the changes in the physical environment at the edge may result in localized shifts in species abundance and composition, called direct biological edge effects (Matlack, 1994; Murcia, 1995). There could be, for instance, with respect to plant species, greater recruitment of successional trees along such edges (Laurance et al., 1998). Such changes may alter the "original" distribution of dispersal syndromes imposed by species or individuals present before fragmentation, one of the called indirect biological edge effects (sensu Murcia, 1995). Composition in plant communities and distribution, abundance, and coexistence of plant species cannot be explained without simultaneously considering environmental heterogeneity and dispersal (Svenning and Skov, 2002).

However, cerrado sensu stricto fragments do not present forest physiognomies (Coutinho, 1990). With the exception of the possible changes in environmental conditions driven by chemical compounds (chemical fertilizers on an agricultural matrix, for instance), we expect that the physical environment in cerrado sensu stricto will not vary towards the fragments interior. In cerrado sensu stricto fragments within an agricultural matrix in NE Brazil, woody species composition, vegetation structure, and microclimatic variables (humidity, air and soil temperature) did not vary with distance from the edge (Queiroga, 2001). Such results indicated that there was no edge effect induced by agriculture in the cerrado fragments studied, which did not mean, however, absence of environmental impact by agriculture (Queiroga, 2001).

Therefore, we postulated that in the woody component of cerrado sensu stricto fragments, the absolute density of anemo-, auto-, and zoochory were constant towards the fragment interior. The aim of this work was to test whether the absolute densities of the anemo-, auto-, and zoochorous individuals varied in function of distance from fragment edge for the woody component in cerrado sensu stricto fragments.

\section{MATERIALS AND METHODS}

We carried out this study in Alto Araguaia, Mato Grosso State, Santa Rita do Araguaia and Mineiros, Goiás State, central-western Brazil, in the southwestern extremity of the Brazilian Central Plateau. Regional climate is classified as Aw (Köppen, 1931), humid tropical with wet summer and dry winter. This region was originally covered mainly by cerrado vegetation, from open (campo limpo, a grassland savanna) to closed (cerradão, a tall woodland) physiognomies, following Coutinho's (1990) classification.

Based on Landsat 7 satellite images (26 June 2002), we selected four fragments covered mainly by cerrado sensu stricto (table 1). All the fragments were located inside private properties and surrounded by agriculture and pasture, in a region economically exploited for the last 30 years. We placed a total of 32 transects in the four fragments: eight in the first and in the fourth, four in the second, and twelve in the third. In each 
fragment, we placed transects systematically, at a distance of $200 \mathrm{~m}$ from each other. In each transect, there were 15 sampling points, $10 \mathrm{~m}$ apart one from another, starting at $10 \mathrm{~m}$ from the fragment edge. We used the point-quarter method (Mueller-Dombois and Ellenberg, 1974; Martins, 1991) to sample the woody component. In each point, we sampled four woody plants with stem diameter at ground level equal or larger than $3 \mathrm{~cm}$ (SMA, 1997). Thus, in the 32 transects, we placed 480 points and sampled 1,920 individuals.

We collected the sampled individuals and identified them by comparison with lodged material at the Federal University of São Carlos herbaria (Hufscar), by comparison with the Emas National Park reference collection (Batalha and Martins, 2002), or by identification keys based on vegetative characters (Mantovani et al., 1985; Batalha et al., 1998; Batalha and Mantovani, 1999). We assigned the dispersal syndrome of species based on the literature (Gottsberger and Silberbauer-Gottsberger, 1983; Batalha and Mantovani, 2000; Spina et al., 2001; Weiser and Godoy, 2001). Occasionally, when there were no data for a given species, we classified its dispersal syndrome based on data for related species of the same genus.

Table 1 - Area (ha) of the four cerrado sensu stricto fragments (Fr.) sampled (central-western Brazil), and approximate location of the lines placed on them.

\begin{tabular}{ccc}
\hline Fr. & Area & Coordinates \\
\hline 1 & 8,278 & $53^{\circ} 02^{\prime}-04^{\prime} \mathrm{W} ; 17^{\circ} 44^{\prime}-45^{\prime} \mathrm{S}$ \\
2 & 1,678 & $53^{\circ} 04^{\prime} 10^{\prime}{ }^{\prime}-31^{\prime}, \mathrm{W} ; 17^{\circ} 40^{\prime}-41^{\prime} \mathrm{S}$ \\
3 & 41,452 & $53^{\circ} 09^{\prime}-11^{\prime} \mathrm{W} ; 17^{\circ} 33^{\prime}-40^{\prime} \mathrm{S}$ \\
4 & 6,666 & $53^{\circ} 26^{\prime}-27^{\prime} \mathrm{W} ; 17^{\circ} 42^{\prime}-43^{\prime} \mathrm{S}$ \\
\hline
\end{tabular}

We counted the number of anemo-, auto-, and zoochorous species and individuals and compared the proportions of these dispersal syndrome classes between species and individuals with the chi-square test (Zar, 1999). We grouped the sampled individuals according to their distance from edge; for a given distance, we sampled 128 individuals (four individuals/point and 32 points for each distance). We counted the number of anemo-, auto-, and zoochorous individuals grouped in each distance from the edge and calculated the absolute density of such individuals using the following equation (modified from Martins, 1991):

$$
A D_{s}=n_{s} \times T D / N
$$

in which $A D_{S}=$ absolute density of the individuals with a given dispersal syndrome in each distance from the edge; $n_{s}=$ number of individuals with a given dispersal syndrome in each distance from the edge; $T D=$ total density, i.e., the total number of individuals, independently of the dispersal syndrome, per area unit, in each distance from the edge; $N=$ total number of individuals, independently of the dispersal syndrome, in each distance from the edge.

We obtained $T D$ from the following equation (modified from Martins, 1991):

$$
T D=V \times N^{2} /\left(\sum_{i=1}^{N} C I D_{i}\right)
$$

in which $V=$ value (meters) of the considered area unit $\left(1\right.$ ha $\left.=10,000 \mathrm{~m}^{2}\right) ; C I D_{i}=$ corrected individual distance of each individual, independently of the dispersal syndrome.

We calculated $C I D_{i}$ from the following formula (Martins, 1991):

$$
C I D_{i}=I D+I R
$$

where $I D=$ individual distance from the point to the tree $(\mathrm{m}) ; I R=$ value of the radius of the sampled individual.

After that, we used regression analyses (Zar, 1999) to test whether the absolute density of anemo-, auto-, and zoochorous individuals varied with distance from edge. In the regression analyses, "distance from edge" was the independent variable and "absolute density of anemo-, auto-, or zoochorous individuals" was the dependent one. 


\section{RESULTS}

In the 32 transects, we sampled 1,920 woody individuals, belonging to 113 species and 37 families (table 2). Anemochory was the dispersal syndrome for 29 species $(25.66 \%)$ and 404 individuals (21.04\%); autochory, for nine species $(7.96 \%)$ and 94 individuals (4.90\%); and zoochory, for 75 species $(66.37 \%)$ and 1,422 individuals $(74.06 \%)$. The proportions of the dispersal syndrome classes did not differ significantly between species and individuals $\left(\chi^{2}=\right.$ 3.91, $\mathrm{p}=0.16)$.

We calculated the absolute density of individuals per dispersal syndrome in relation to distance from edge and did regression analysis for each syndrome. The absolute densities of anemo- and autochorous individuals did not vary in relation to distance from edge $\left(\mathrm{R}^{2}=0.01, \mathrm{p}=0.69 ; \mathrm{R}^{2}=0.18\right.$, $\mathrm{p}=0.11$, respectively; Fig. 1). On the other hand, the absolute density of zoochorous individuals increased with distance from edge $\left(\mathrm{R}^{2}=0.29, \mathrm{p}=\right.$ 0.04; Fig. 1).
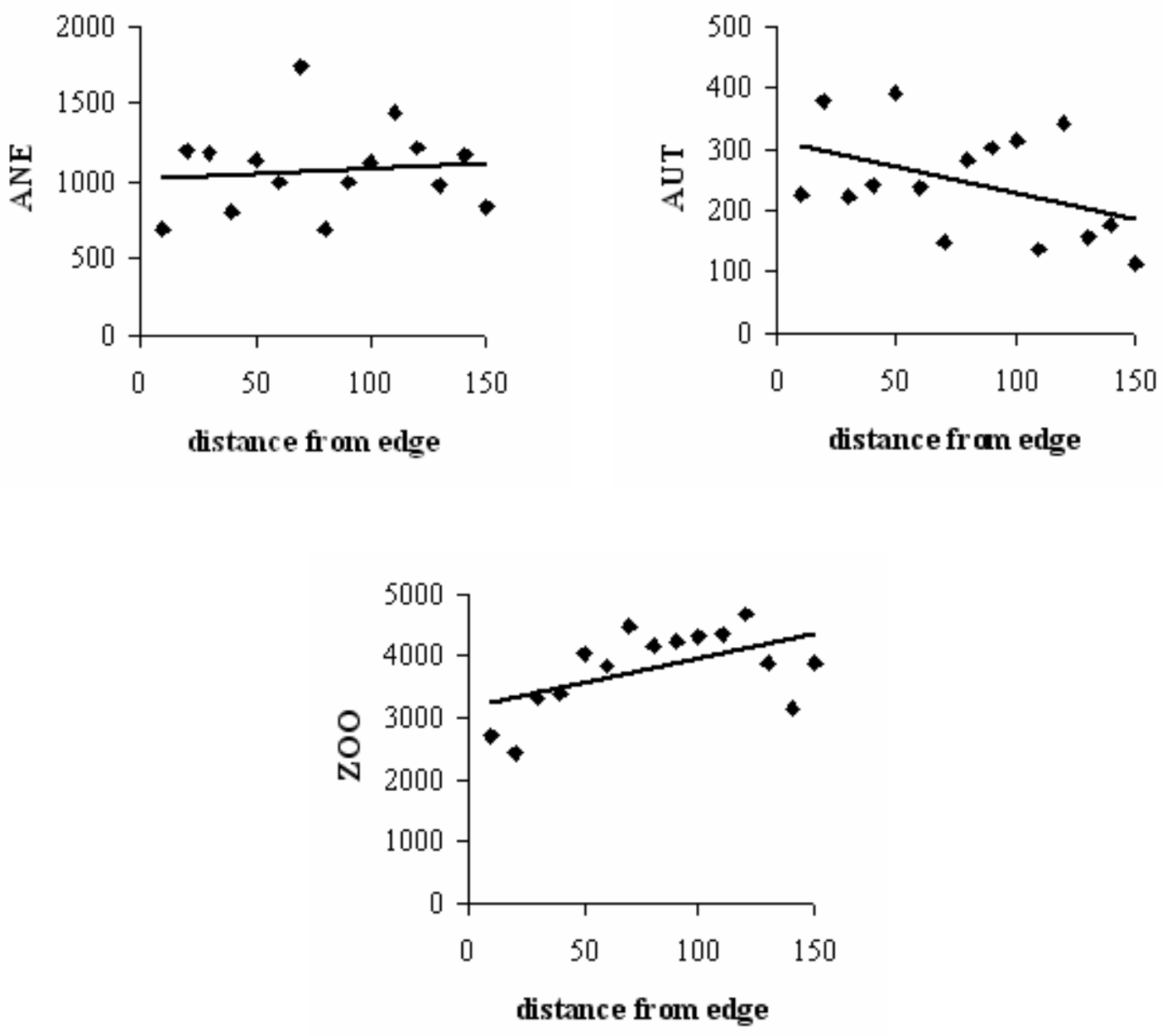

Figure 1 - Absolute density of anemo- (“ANE”), auto- (“AUT”), and zoochorous (“ZOO”) individuals in relation to edge distance (respectively, $\mathrm{R} 2=0.01, \mathrm{p}=0.69 ; \mathrm{R} 2=0.18$, $\mathrm{p}=0.11$; and $\mathrm{R} 2=0.29, \mathrm{p}=0.04$ ) in four cerrado sensu stricto fragments from central-western Brazil. 
Table 2 - Species sampled in four cerrado sensu stricto fragments (central-western Brazil) with their dispersal syndromes (Disp.). Ane = anemochorous, Aut = autochorous, Zoo = zoochorous.

\begin{tabular}{|c|c|}
\hline Family/ Species & Disp \\
\hline \multicolumn{2}{|l|}{ ANACARDIACEAE } \\
\hline Anacardium humile A. St-Hill. & Zoo \\
\hline Tapirira guianensis Aubl. & Zoo \\
\hline \multicolumn{2}{|l|}{ ANNONACEAE } \\
\hline Annona coriacea Mart. & Zoo \\
\hline Annona crassiflora Mart. & Zoo \\
\hline Bocageopsis mattogrossensis (R.E. Fries) R.E. Fries & Zoo \\
\hline Duguetia furfuracea (A. St-Hil.) Benth.and Hook. f. & Zoo \\
\hline \multicolumn{2}{|l|}{ APIACEAE } \\
\hline Didymopanax macrocarpum (Cham. and Schltdl.) & Zoo \\
\hline Didymopanax vinosum (Cham. and Schltdl.) Seem & Zoo \\
\hline \multicolumn{2}{|l|}{ APOCYNACEAE } \\
\hline Aspidosperma macrocarpon Mart. & Ane \\
\hline Aspidosperma nobile Müll.Arg. & Ane \\
\hline Aspidosperma tomentosum Mart. & Ane \\
\hline Hancornia speciosa Gomez & Zoo \\
\hline Himatanthus obovatus (Müll. Arg.) Woods. & Ane \\
\hline \multicolumn{2}{|l|}{ ASTERACEAE } \\
\hline Eremanthus erythropappus Sch. Bip. & Ane \\
\hline Eremanthus glomerulatus Less. & Ane \\
\hline Piptocarpha rotundifolia (Less.) Baker & Ane \\
\hline \multicolumn{2}{|l|}{ BIGNONIACEAE } \\
\hline Tabebuia aurea (Silva Manso) S. Moore & Ane \\
\hline Tabebuia ochracea (Cham.) Standl. & Ane \\
\hline \multicolumn{2}{|l|}{ CARYOCARACEAE } \\
\hline Caryocar brasiliense Cambess. & Zoo \\
\hline \multicolumn{2}{|l|}{ CELASTRACEAE } \\
\hline Peritassa campestris (Cambess.) AC. Sm. & Zoo \\
\hline Plenckia populnea Reissek & Ane \\
\hline \multicolumn{2}{|l|}{ CHRYSOBALANACEAE } \\
\hline Couepia grandiflora (Mart. and Zucc.) Benth. ex Hook. f. & Zoo \\
\hline Licania humilis Cham. and Schltdl. & Zoo \\
\hline \multicolumn{2}{|l|}{ CLUSIACEAE } \\
\hline Kielmeyera coriacea Mart. & Ane \\
\hline Kielmeyera rubriflora Cambess. & Ane \\
\hline \multicolumn{2}{|l|}{ COMBRETACEAE } \\
\hline Buchenavia tomentosa Eichl. & Zoo \\
\hline \multicolumn{2}{|l|}{ CONNARACEAE } \\
\hline Connarus suberosus Planch. & Zoo \\
\hline Rourea induta Planch. & Zoo \\
\hline \multicolumn{2}{|l|}{ DILLENIACEAE } \\
\hline Davilla elliptica A. St-Hil. & Zoo \\
\hline \multicolumn{2}{|l|}{ EBENACEAE } \\
\hline Diospyros hispida A. DC. & Zoo \\
\hline \multicolumn{2}{|l|}{ ERYTHROXYLACEAE } \\
\hline Erythroxylum campestre A. St-Hil. & Zoo \\
\hline Erythroxylum suberosum A. St-Hil. & Zoo \\
\hline Erythroxylum tortuosum A. St-Hil. & Zoo \\
\hline
\end{tabular}




\begin{tabular}{|c|c|}
\hline Family/ Species & Disp \\
\hline \multicolumn{2}{|l|}{ EUPHORBIACEAE } \\
\hline Manihot caerulescens Pohl & Aut \\
\hline Pera glabatra (Schott) Baill. & Zoo \\
\hline \multicolumn{2}{|l|}{ FABACEAE } \\
\hline Acosmium subelegans (Mohl.) Yakovlev & Ane \\
\hline Anadenanthera falcata (Benth.) Speg. & Aut \\
\hline Andira anthelmia (Vell. Conc.) Macbr. & Zoo \\
\hline Andira cuiabensis Benth. & Zoo \\
\hline Andira laurifolia Benth & Zoo \\
\hline Andira vermifuga (Mart.) Benth. & Zoo \\
\hline Bauhinia rufa Steud. & Aut \\
\hline Bowdichia virgilioides Kunth & Ane \\
\hline Dalbergia cuiabensis Benth. & Ane \\
\hline Dalbergia miscolobium Benth. & Ane \\
\hline Dimorphandra mollis Benth. & Zoo \\
\hline Dioclea bicolor Benth. & Aut \\
\hline Diptychandra aurantiaca Tul. & Aut \\
\hline Harpalyce brasiliana Benth. & Ane \\
\hline Hymenaea stigonocarpa Mart. & Zoo \\
\hline Machaerium acutifolium Vogel & Ane \\
\hline Plathymenia reticulata Benth. & Aut \\
\hline Sclerolobium aureum (Tul.) Baill. & Ane \\
\hline Sclerolobium paniculatum Vogel & Ane \\
\hline Stryphnodrendon obovatum Benth. & Aut \\
\hline Vatairea macrocarpa (Benth.) Ducke & Ane \\
\hline \multicolumn{2}{|l|}{ FLACOURTIACEAE } \\
\hline Casearia sylvestris $\mathrm{Sw}$. & Zoo \\
\hline \multicolumn{2}{|l|}{ ICACINACEAE } \\
\hline Emmotum nitens (Benth.) Miers & Zoo \\
\hline \multicolumn{2}{|l|}{ LAURACEAE } \\
\hline Ocotea corymbosa (Meiss.) Mez & Zoo \\
\hline \multicolumn{2}{|l|}{ LECYTHIDACEAE } \\
\hline Eschweilera nana (O. Berg) Miers & Ane \\
\hline \multicolumn{2}{|l|}{ LOGANIACEAE } \\
\hline Strychnos pseudoquina A. St-Hil. & Zoo \\
\hline \multicolumn{2}{|l|}{ LYTHRACEAE } \\
\hline Lafoensia pacari A. St-Hil. & Aut \\
\hline \multicolumn{2}{|l|}{ MALPIGHIACEAE } \\
\hline Banisteriopsis stellaris (Griseb.) B. Gates & Ane \\
\hline Byrsonima basiloba A. Juss. & Zoo \\
\hline Byrsonima coccolobifolia A .Juss. & Zoo \\
\hline Byrsonima crassa Nied. & Zoo \\
\hline Byrsonima intermedia A. Juss. & Zoo \\
\hline Peixotoa reticulata Griseb. & Ane \\
\hline \multicolumn{2}{|l|}{ MALVACEAE } \\
\hline Eriotheca gracilipes (K. Schum.) A. Robyns & Ane \\
\hline
\end{tabular}




\begin{tabular}{|c|c|}
\hline Family/Species & Disp \\
\hline \multicolumn{2}{|l|}{ MELASTOMATACEAE } \\
\hline Miconia albicans Triana & Zoo \\
\hline Miconia fallax A. DC. & Zoo \\
\hline Miconia ferruginata A. DC. & Zoo \\
\hline Miconia ligustroides (A. DC.) Naud. & Zoo \\
\hline Mouriri elliptica Mart. & Zoo \\
\hline \multicolumn{2}{|l|}{ MYRISTICACEAE } \\
\hline Virola sebifera Aubl. & Zoo \\
\hline \multicolumn{2}{|l|}{ MYRTACEAE } \\
\hline Campomanesia adamantium (Cambess.) O. Berg & Zoo \\
\hline Campomanesia pubescens (A. DC.) O. Berg & Zoo \\
\hline Eugenia aurata $\mathrm{O}$. Berg & Zoo \\
\hline Eugenia bimarginata A. DC. & Zoo \\
\hline Eugenia piauhiensis O. Berg & Zoo \\
\hline Eugenia punicifolia (Kunth) A. DC. & Zoo \\
\hline Myrcia bella Cambess. & Zoo \\
\hline Myrcia camapuanensis N.F.E. Silveira & Zoo \\
\hline Myrcia crassifolia (O. Berg) Kiaersk. & Zoo \\
\hline Myrcia fallax (Rich.) A. DC. & Zoo \\
\hline Myrcia guianensis A. DC. & Zoo \\
\hline Myrcia laruotteana Cambess. & Zoo \\
\hline Myrcia linguaeformis Kiaersk. & Zoo \\
\hline Myrcia rhodeosepala Kiaersk. & Zoo \\
\hline Myrcia torta A. DC. & Zoo \\
\hline Myrcia sp. nov. & Zoo \\
\hline Myrcia uberavensis O. Berg & Zoo \\
\hline Psidium laruotteanum Cambess. & Zoo \\
\hline \multicolumn{2}{|l|}{ NYCTAGINACEAE } \\
\hline Guapira noxia (Netto) Lund. & Zoo \\
\hline Neea theifera Oerst. & Zoo \\
\hline \multicolumn{2}{|l|}{ OCHNACEAE } \\
\hline Ouratea acuminata (A. DC.) Engl. & Zoo \\
\hline Ouratea castanaefolia (A. DC.) Engl. & Zoo \\
\hline Ouratea semiserrata (Mart. and Nees) Engl. and Mart. & Zoo \\
\hline Ouratea spectabilis (Mart.) Engl. & Zoo \\
\hline \multicolumn{2}{|l|}{ PROTEACEAE } \\
\hline Roupala montana Aubl. & Aut \\
\hline \multicolumn{2}{|l|}{ RUBIACEAE } \\
\hline Chomelia ribesioides Benth.ex A.Gray & Zoo \\
\hline Genipa americana $\mathrm{L}$. & Zoo \\
\hline Palicourea rigida Kunth & Zoo \\
\hline Tocoyena formosa (Cham. and Schltdl.) K. Schum. & Zoo \\
\hline \multicolumn{2}{|l|}{ SAPINDACEAE } \\
\hline Toulicia tomentosa Radlk. & Zoo \\
\hline \multicolumn{2}{|l|}{ SAPOTACEAE } \\
\hline Pouteria ramiflora (Mart.) Radlk. & Zoo \\
\hline Pouteria torta (Mart.) Radlk. & Zoo \\
\hline
\end{tabular}




\begin{tabular}{lcc}
\hline & Family/ Species & Disp \\
\hline SIMAROUBACEAE & Zoo \\
Simarouba amara Aubl. & \\
STYRACACEAE & Zoo \\
Styrax ferrugineum Nees and Mart. & \\
VOCHYSIACEAE & Ane \\
Qualea grandiflora Mart. & Ane \\
Qualea multiflora Mart. & Ane \\
Qualea parviflora Mart. & Ane \\
Vochysia thyrsoidea Pohl & & \\
\hline
\end{tabular}

\section{DISCUSSION}

In the sampled fragments, the proportions of the dispersal syndromes among species did not differ to the one among individuals, pointing out that this pattern was mantained either when species abundance was taken into account or when not. The prevalence of zoochory in the community studied highlighted the importance of animals for dispersal. The maintenance of species richness and genetic diversity of plant populations in regenerating, fragmented, or intact areas critically depends on vertebrate populations required for seed dispersal (Gorchov et al., 1993). Fleshy fruits of zoochorous species, on the other hand, are an important resource for birds and mammals, because they are nutritious and ready to consumption (Howe and Smallwood, 1982; Jordano, 1992).

By analyzing the absolute densities of the dispersal syndromes in relation to the distance from edge, we observed that, as expected, neither anemo- nor autochory varied. Zoochory, however, varied in relation to distance from edge, increasing toward the fragment interior, contrary to our expectations. The non-variation of anemo- and autochory in relation to distance indicated that abiotic factors (solar radiation, air moisture, air temperature, wind speed, soil moisture, and soil temperature) did not differ between edge and interior of the fragments studied. Such homogeneity could be a consequence of the physiognomy of the sampled vegetation. The cerrado sensu stricto physiognomy fits the definition of a tropical savanna (Bourlière and Hadley, 1983), so the differences in microclimatic conditions between edge and core regions of the fragments might be not as large as those in forest fragments (Queiroga, 2001; Martins and Batalha, 2007). Edge influence on species composition is less likely in landscapes naturally characterized by a patchy composition (e.g., of tree-, shrub- and grass-dominate cover), because they may have more edge-adapted species (Harper et al., 2005). In a reserve covered by patches of cerrado sensu stricto and campo cerrado, intensively invaded by alien grasses, graminoid species do not seem to be affected by the distance of the border (Pivello et al., 1999).

Seed dispersal should be influenced by the permeability of the vegetation (physical obstruction imposed by the architecture of plants) to the flux of seeds (Willson and Crome, 1989). Wind-dispersed seeds crossing a thinned vegetation edge disperse farther into the fragment interior (Cadenasso and Pickett, 2001). As cerrado sensu stricto fragments presents a thinner edge than forest fragments, the dispersal distance achieved by seeds carried by wind into such fragments could be higher, which would result in a homogeneous distribution of anemochorou species in relation to the distance from the edge. We could adopt the same rationale with respect to autochorous species, which often use the influence of abiotic factors (wind, rain, alternating wet and dry seasons) to disperse their seeds. However, if microclimatic variables did not vary, what would be driving the variation of zoochory in relation to the distance from edge?

It seems that other factors rather than microclimatic conditions are shifting zoochorous individuals to the interior of the fragments studied. Human pressure is a strong candidate, but we cannot analyze it in a deeper way, as we do not have data of matrix composition. The nature of human land use in the matrix will affect fragmentation impacts, as the matrix is fundamentally associated with human pressure (Kupfer et al., 2006). Whereas vegetation clearing for forestry or agriculture tends to increase hunting (Bousquet et al., 2001), cutting for housing 
contributes to light, noise, and pets near edges (Theobald et al., 1997) - edges will generally have more activity than the interior (Kupfer et al., 2006).

The behavior of the absolute densities of the dispersal syndromes in relation to the distance from edge should be studied to a more detailed view of the dispersal classification, because there are subgroups of the same dispersal group that present dispersal abilities completely different. For instance, myrmecochorous species may be grouped as poor dispersers, whereas epizoo- and endozoochorous (except for low understorey herbs) may be grouped as good dispersers (Svenning and Skov, 2002).

The observed spatial patterns may reflect that communities show fine-scale structure above and beyond that generated by local dispersal (Purves and Law, 2002). It means that certain species would be more strongly associated than others and some of this variation could be attributed to plant traits; species with more disparate seed or plant sizes would have more negative associations (Turnbull et al., 2004). Vegetative propagation, very common in the cerrado (Rizzini, 1965; Hoffmann, 1998), could be another cause of plant aggregation (Purves and Law, 2002), but the change of the reproductive mode from propagation via seeds to vegetative depending on local circumstances (Prati and Schmid, 2000; Kanno and Seiwa, 2004; Gros et al., 2006) in cerrado patches remains to be investigated.

We made no measurements of seed dispersal, seed deposition, or environmental conditions; even if empirical support was lacking, our evidences may be regarded as patterns generating postulates and hypotheses (Levine and Murrell, 2003). For future researches, we also suggest focusing on how processes in the matrix contribute to patterns of species persistence across the modified landscapes, instead of solely documenting fragmentation effects from a remnant-based perspective. The extent, intensity, and permanence of alterations to the matrix will have an overriding influence on the area and isolation effects and will emphasize the potential roles of the matrix as not only a barrier but also as habitat, source, and conduit (Kupfer et al., 2006).

\section{ACKNOWLEDGMENTS}

We are grateful to Fapesp, for the scholarship conceded to the first author; to Conservação Internacional, for financial support (especially to Mário Barroso Ramos-Neto and Paulo Gustavo Prado); to Emas Foundation and Oréades Geoprocessing, for logistic support.

\section{RESUMO}

As principais forças seletivas que afetam as estratégias de frutificação estão relacionadas ao ambiente em que as plantas ocorrem. Como fragmentos de cerrado sensu stricto são savânicos, as condições microclimáticas não devem variar em relação à distância da borda. Assim, postulamos que a importância das diferentes síndromes de dispersão não varia da borda ao interior de um fragmento de vegetação. O objetivo deste trabalho foi testar, em quatro fragmentos de cerrado sensu stricto (centro-oeste do Brasil), se a densidade absoluta de indivíduos anemo, auto e zoocóricos variava em função da distância da borda. Segundo nossos resultados, a densidade absoluta de indivíduos anemo e autocóricos não variou significativamente borda em direção ao interior dos fragmentos, enquanto que a dos indivíduos zoocóricos aumentou, indicando que existem outros fatores, que não as condições abióticas, deslocando as espécies zoocóricas para o interior dos fragmentos de cerrado sensu stricto.

\section{REFERENCES}

Batalha, M. A.; Aragaki, S. and Mantovani, W. (1998), Chave de identificação das espécies vasculares do cerrado em Emas (Pirassununga, SP) baseada em caracteres vegetativos. Bol. Bot. Univ. São Paulo, 17, 85-108.

Batalha, M. A. and Mantovani, W. (1999), Chaves de identificação das espécies vegetais vasculares baseada em caracteres vegetativos para a ARIE Cerrado Péde-Gigante (Santa Rita do Passa Quatro, SP). Rev. Inst. Flor., 11, 137-158. 
Batalha, M. A. and Mantovani, W. (2000), Reproductive phenological patterns of cerrado plant species at the Pé-de-Gigante Reserve (Santa Rita do Passa Quatro, SP, Brazil): a comparison between the herbaceous and woody floras. Rev. Bras. Biol., 60, 129-145.

Batalha, M. A. and Martins, F. R. (2002), The vascular flora of the cerrado in Emas National Park (Goiás, central Brazil). Sida, 20, 295-312.

Batalha, M. A. and Martins, F. R. (2004), Reproductive phenology of the cerrado plant community in Emas National Park (central Brazil). Aust. J. Bot., 52, 149161.

Batalha, M. A. and Martins, F. R. (2007), The vascular flora of the cerrado in Emas National Park (central Brazil): a savanna flora summarized. Braz. Arch. Biol. Technol., 50, 269-277.

Bourlière, F. and Hadley, M. (1983), Present-day savannas: an overview. In: Goodall, D. W. (Ed.). Ecosystems of the world - tropical savannas. Amsterdam: Elsevier. pp. 1-17.

Bousquet, F.; Le Page, C.; Bakam, I. and Takforyan, A. (2001), Multiagent simulations of hunting wild meat in a village in eastern Cameroon. Ecol. Model., 138, 331-346.

Cadenasso, M. L. and Pickett, S. T. A. (2001), Effect of edge structure on the flux of species into forest interiors. Conserv. Biol., 15, 91-97.

Coutinho, L. M. (1990), Fire in the ecology of the Brazilian cerrado. In: Goldammer, J. G. (Ed.). Fire in the tropical biota. Berlin: Springer. pp. 81-103.

Fuentes, M. (2000), Frugivory, seed dispersal and plant community ecology. TREE, 15, 487-488.

Gorchov, D. L.; Cornejo, F.; Ascorra, C. and Jaramillo, M. (1993), The role of seed dispersal in the natural regeneration of rain forest after strip-cutting in the Peruvian Amazon. Vegetatio, 107, 339-349.

Gottsberger, G. and Silberbauer-Gottsberger, I. (1983), Dispersal and distribution in the cerrado vegetation of Brazil. Sonderbd. Naturwiss. Ver. Hamburg, 7, 315352.

Gros, A.; Poethke, H. J. and Hovestadt, T. (2006), Evolution of local adaptations in dispersal strategies. Oikos Online Early, DOI: 10.1111/j.2006.00301299.14909.x.

Harper, K. A.; Macdonald, S. E.; Burton, P. J.; Chen, J.; Brosofske, K. D.; Saunders, S. C.; Euskirchen, E. S.; Roberts, D.; Jaiteh, M. S. and Esseen, P. (2005), Edge influence on forest structure and composition in fragmented landscapes. Conserv. Biol., 19, 768-782.

Hoffmann, W. (1998), Post-burn reproduction of woody plants in a neotropical savanna: the relative importance of sexual and vegetative reproduction. $J$. Appl. Ecol., 35, 422-433.

Howe, H. F. and Smallwood, J. (1982), Ecology of seed dispersal. Ann. Rev. Ecol. Syst., 13, 201-228.

Hughes, L.; Dunlop, M.; French, K.; Leishman, M.R.; Rice, B.; Rodgerson, L. and Westoby, M. (1994),
Predicting dispersal spectra: a minimal set of hypotheses based on plant attributes. J. Ecol., 82, 933-950.

Jordano, P. (1992), Fruits and frugivory. In: Fenner, M. (Ed.). Seeds: the ecology of regeneration in plant communities. Wallingford: Commonwealth agricultural Bureau International. pp. 105-156.

Kanno, H. and Seiwa, K. (2004), Sexual vs vegetative reproduction in relation to forest dynamics in the understorey shrub, Hydrangea paniculata (Saxifragaceae). Plant Ecol., 170, 43-53.

Köppen, W. (1948), Climatología. Fondo de Cultura Económica, México.

Kupfer, J. A.; Malanson, G. P. and Franklin, S. B. (2006), Not seeing the ocean for the islands: the mediating influence of matrix-based processes on forest fragmentation effects. Global Ecol. Biogeogr., 15, 8-20.

Laurance, W. F.; Ferreira, L. V.; Rankin-de Merona, J. M.; Laurance, S. G.; Hutchings, R. W. and Lovejoy, T. E. (1998), Effects of forest fragmentation on recruitment patterns in Amazonian tree communities. Conserv. Biol., 12, 460-464.

Levin, S. A.; Muller-Landau, H. C.; Nathan, R. and Chave, J. (2003), The ecology and evolution of seed dispersal: a theoretical perspective. Ann. Rev. Ecol. Evol. Syst., 34, 575-604.

Levine, J. M. and Murrell, D. J. (2003), The community-level consequences of seed dispersal patterns. Ann. Rev. Ecol. Evol. Syst., 34, 549-74.

Lindenmayer, D. B. and Fischer, J. (2006), Habitat fragmentation and landscape change: an ecological and conservation synthesis. Island Press.

Mantovani, W.; Leitão-Filho, H. F. and Martins, F. R. (1985), Chave baseada em caracteres vegetativos para a identificação de espécies lenhosas do cerrado da Reserva Biológica de Moji Guaçu, Estado de São Paulo. Hoehnea, 12, 35-56.

Martins, F. R. (1991), Estrutura de uma floresta mesófila. Edunicamp, Campinas.

Martins, F. Q. and Batalha, M. A. (2007), Vertical and horizontal distribution of pollination systems in cerrado fragments of Central Brazil. Braz. Arch. Biol. Technol., 50, 503-514.

Matlack, G. R. (1994), Vegetation dynamics of the forest edge: trends in space and successional time. $J$. Ecol., 82, 113-123.

Mueller-Dombois, D. and Ellenberg, H. (1974), Aims and methods of vegetation ecology. John Willey and Sons, New York.

Murcia, C. (1995), Edge effects in fragmented forests: implications for conservation. TREE, 10, 58-62.

Nathan, R. and Muller-Landau, H. C. (2000), Spatial patterns of seed dispersal, their determinants and consequences for recruitment. TREE, 15, 278-285.

Oliveira, P. E. (1998), Fenologia e biologia reprodutiva das espécies de cerrado. In: Sano, S. M. and Almeida, 
S. P. (Eds.). Cerrado: ambiente e flora. Brasília: Embrapa. pp. 169-192.

Oliveira, P. E. A. M. and Moreira, A. G. (1992), Anemocoria em espécies de cerrado e mata de galeria de Brasília, DF. Revista Brasileira de Botânica, 15, 163-174.

Opler, P. A.; Frankie, G. W. and Baker, H. G. (1980), Comparative phenology studies of treelet and shrub species in tropical wet and dry forest in the lowland of Costa Rica. J. Ecol., 68, 189-209.

Pijl, L. van der (1972), Principles of dispersal in higher plants. Springer, Berlin.

Pivello, V. R.; Shida, C. N. and Meirelles, S. T. (1999), Alien grasses in Brazilian savannas: a threat to the biodiversity. Biodiv. Conserv., 8, 1281-1294.

Prati, D. and Schmid, B. (2000), Genetic differentiation of lifehistory traits within populations of the clonal plant Ranunculus reptans. Oikos, 90, 442-456.

Purves, D. W. and Law, R. (2002), Fine-scale spatial structure in a grassland community: quantifying the plant's-eye view. J. Ecol.; 90, 121-129.

Queiroga, J. L. (2001), Efeito de borda em fragmentos de cerrado em áreas de agricultura do Maranhão, Brasil. Msc. Thesis, Universidade Estadual de Londrina, Londrina, Brazil.

Ramos, F. N. and Santos, F. A. M. (2006), Microclimate of Atlantic forest fragments: regional and local scale heterogeneity. Braz. Arch. Biol. Technol., 49, 935-944.

Ratter, J. A.; Ribeiro, J. F. and Bridgewater, S. (1997), The Brazilian cerrado vegetation and threats to its biodiversity. Ann. Bot., 80, 223-230.

Rizzini, C. T. (1965), Experimental studies on seedling development of cerrado woody plants. Ann. Mo. Bot. Gard., 52, 410-426.

SMA - Secretaria de Estado do Meio Ambiente. (1997), Cerrado: bases para conservação e uso sustentável das áreas de cerrado do estado de São Paulo. Secretaria de Estado do Meio Ambiente, São Paulo.
Spina, A. P.; Ferreira, W. M. and Leitão Filho, H. F. (2001), Floração, frutificação e síndromes de dispersão de uma comunidade de floresta de brejo na região de Campinas (SP). Acta Bot. Bras., 15, 349368.

Svenning, J. C. and Skov, S. (2002), Mesoscale distribution of understorey plants in temperate forest (Kalo, Denmark): the importance of environment and dispersal. Plant Ecol., 160, 169-185.

Theobald, D. M.; Miller, J. R. and Hobbs, N. T. (1997), Estimating the cumulative effects of development on wildlife habitat. Landscape Urban Plann. J., 39, 2536.

Turnbull, L. A.; Coomes, D.; Hector, A. and Rees, M. (2004), Seed mass and the competition/colonization trade-off: competitive interactions and spatial patterns in a guild of annual plants. J. Ecol., 92, 97-109.

Weiser, V. L. and Godoy, S. A. P. (2001), Florística em um hectare de cerrado stricto sensu na ARIE Cerrado Pé-de-Gigante, Santa Rita do Passa Quatro, SP. Acta Bot. Bras., 15, 201-212.

Willson, M. F. and Crome, F. H. J. (1989), Patterns of seed rain at the edge of a tropical Queensland rain forest. J. Trop. Ecol., 5, 301-308.

Zar, J. H. (1999), Biostatiscal analysis. Prentice-Hall, New Jersey.

Received: June 14, 2006; Revised: February 27, 2007; Accepted: January 27, 2009. 